NBER WORKING PAPER SERIES

THE RETURNS TO COMPUTER USE

REVISITED: HAVE PENCILS CHANGED

THE WAGE STRUCTURE TOO?

John E. DiNardo

Jörn-Steffen Pischke

Working Paper 5606

\author{
NATIONAL BUREAU OF ECONOMIC RESEARCH \\ 1050 Massachusetts Avenue \\ Cambridge, MA 02138 \\ June 1996
}

This paper is part of NBER's research program in Labor Studies. Any opinions expressed are those of the authors and not those of the National Bureau of Economic Research.

(C) 1996 by John E. DiNardo and Jörn-Steffen Pischke. All rights reserved. Short sections of text, not to exceed two paragraphs, may be quoted without explicit permission provided that full credit, including $(\mathcal{C}$ notice, is given to the source. 
NBER Working Paper 5606

June 1996

\title{
THE RETURNS TO COMPUTER USE \\ REVISITED: HAVE PENCILS CHANGED \\ THE WAGE STRUCTURE TOO?
}

\begin{abstract}
Are the large measured wage differentials associated with on-the-job computer use productivity gains or the result of unobserved heterogeneity? We examine this issue with three large cross-sectional surveys from Germany. First, we confirm that the estimated wage differentials associated with computer use in Germany are very similar to the U.S. differential. Second, using the same techniques we also measure large differentials for on-the-job use of calculators, telephones, pens or pencils, or for those who work while sitting down. Along with our reanalysis of the U.S. data these findings cast some doubt on the interpretation of the computer-use wage differential as reflecting productivity effects arising from the introduction of computers in the workplace.
\end{abstract}

John E. DiNardo

Department of Economics

University of California

Irvine, CA 92717

and NBER
Jörn-Steffen Pischke

Department of Economics

Massachusetts Institute of Technology

Cambridge, MA 02139

and NBER 


\section{Introduction}

It seems undeniable that the increase in the skill premium in the advanced world is primarily the result of skill-biased technological change.

Paul Krugman, a Stanford University economist (1994)

I don't think a guy will be able to go into his country club if he doesn't have a CAD/CAM [computer aided manufacturing and design system] system in his factory. He's got to be able to talk about his CAD/CAM system as he tees off on the third tee - or he will be embarrassed.

Joseph Engelberger, founder of Unimation, the first major U.S. robot manufacturer (Schlesinger 1983)

There has been a large widening of wage differentials in the U.S. and other industrialized countries during the past 15 years. Many researchers have attributed this change to skill-biased technological change (see Bound and Johnson (1992)). The evidence supporting a major role for skill-biased technical change, however, is primarily inferential. Wages for highly skilled workers in the U.S. have risen while the number of skilled workers has risen as well. In the view of many, therefore, this requires an explanation based on an increased demand for more skilled labor. Since the 1980's witnessed great technological advances, including cheaper and more powerful computing technology, technical change has been considered a plausible explanation. ${ }^{1}$ Support for a major role for skill-biased technological change, moreover, has been strengthened by the perceived inability of other candidate explanations to explain the dramatic changes in the observed pattern of wages over time in the U.S.

Until recently, changes in the wage structure have rarely been directly linked to observable technical developments that are presumably transforming workplaces and the distribution of wages. A notable exception is Alan

\footnotetext{
${ }^{1}$ Indeed, in 1983, Time Magazine, a weekly U.S. news publication, gave its much vaunted "Man of the Year" award to the Computer.
} 
Krueger's (1993) careful and influential study that finds that the use of a computer at work is associated with a 10-15 percent wage differential. In this paper, we attempt to shed some new light on the question of whether the measured returns to computer use reflect productivity differences due to the introduction of computers in the workplance - and hence provide a potential explanation for wage structure changes - or whether these returns merely reflect unobserved heterogeneity. If this latter view is correct, the direct evidence for skill-biased technical change in explaining changes is severely undermined.

In this paper, we first present evidence from German data that shows that the basic pattern of computer use and the wage premium for computer users is very similar to the findings for the U.S., which suggests that an analysis of the German data is informative. Second, since the German data contains detailed information on the tools used by workers and the knowledge they have about these tools, we can apply conventional techniques to evaluate the returns to these other tools, as well as computers. When we do so, we find for example, that the measured return to the use of pencils at work is almost as large and robust as the measured return for computer use. Since we do not believe that pencils changed the wage structure, this would appear to undermine the view that the coefficient on computers provides direct evidence on the role of skill-biased technological change. Instead, the results seem to suggest that computer users possess unobserved skills that are rewarded in the labor market, or that computers were first introduced in higher paying occupations or jobs. We argue that all the results in Krueger (1993) can be interpreted in this light. We review some related literature on this issue and present additional evidence of our own. The remainder of the paper is organized as follows. The next section describes the German data sets we use. Section 3 discuses the measured returns to the use of tools in the U.S. and Germany. Section 4 discusses various interpretations of the empirical evidence and the final section concludes.

\section{The Data}

Our German data come from three cross-sections of the West German "Qualification and Career Survey," conducted in 1979, in 1985/86, and in 1991/92 by the Federal Institute for Vocational Training (BIBB) and the Institute for 
Labor Market Research (IAB). The surveys contain standard demographic and labor market variables but are also particularly rich in details about workers' jobs, job attributes, the tools used in these jobs, the skills necessary to perform a job, and how these skills were obtained. The sampling frame for the survey is the German employed population age 16 to 65 . Each survey has slightly less than 30,000 respondents. We use the largest sample possibly, only deleting a observations which do not have information on the variables we analyze. The questions in the three surveys are similar but not exactly comparable. We report details on the variables we use below.

The questions on computer use differ slightly between the 1979 survey and the later waves. For the 1979 survey we combine affirmative answers to two questions as computer users. The first asked about the use of "computers, terminals, or monitors," the second inquired about word processors. In the later surveys there are six categories which we combine: computers on shop floors, office computers, PCs, terminals, word processors, and CAD systems. Other questions inquired about the use of computer controlled machinery, but this seems to be different from the concept captured in the questions in the U.S. Current Population Survey used by Krueger (1993).

Table 1 summarizes the probability of using a computer at work for different categories of workers and reproduces a similar tabulation from Krueger (1993). Computer use in the mid 1980s is lower in Germany than in the U.S. but by 1991 the fraction of workers using computers on the job in Germany approaches the U.S. utilization rate. In addition the patterns of use among various labor market groups are very similar. In both countries computers are used predominantly by the more highly educated, by the age group 25-39, by white collar workers, and by full time employees.

\section{The Returns to Computer Use in the U.S. and Germany}

To assess the wage differential associated with using computers we run a number of standard wage regressions. Our dependent variable is the log of gross average hourly earnings. This variable is constructed from monthly 
earnings and usual weekly hours. ${ }^{2}$

The raw log wage differential for computer use in Germany is 0.139 in $1979,0.240$ in $1985 / 86$, and 0.288 in $1991 / 92$. This is somewhat lower than the 0.276 differential for the U.S. in 1984 and 0.325 in 1989. Results from the wage regressions including a computer dummy and other covariates are reported in Table 2. The wage differential for computer use in Germany falls to 0.112 in $1979,0.157$ in $1985 / 86$, and 0.171 in 1991/92 when controls such as education, experience, gender, and others are added to the regression. These differentials resemble relatively closely those found by Krueger which are displayed in the first two columns. As in the U.S., the wage differential associated with computer use in Germany has increased over time.

The basic patterns of computer use in the U.S. and in Germany and the wage differentials associated with computers are very similar. This is true despite the fact that the German labor market is more regulated, pay setting more centralized, and the wage structure more compressed than in the U.S. (see e.g. Krueger and Pischke (1995)). The narrower wage structure in Germany is reflected in the fact that most coefficients in Table 2 tend to be somewhat smaller in Germany than they are for U.S. data. Overall, we thus conclude that the wage differential for computer use is very similar in the two countries, which suggests that the interpretation of the results is also likely to be the same.

\section{A The Returns to Pencils, Telephones and Sitting on the Job in Germany}

In this subsection we compare the patterns of use and the wage differentials associated with computers to those for a set of more commonly-found tools and job attributes which are likely to invite a very different interpretation.

\footnotetext{
${ }^{2}$ The earnings variable in the survey is obtained not as a continuous number but in bracketed form. There are 13 brackets for the 1979 survey, 21 in $1985 / 86$, and 15 in 1991/92. We assigned bracket midpoints to each group. The resulting approximation should be rather good because of the large number of brackets. Adopting a similar specification we find that this earnings variable yields the same return to schooling in 1985/86 as reported by Krueger and Pischke (1995) with a continuous earnings variable for 1988 . Years of education are imputed from information on schools attended and degrees obtained following Krueger and Pischke (1995).
} 
Table 3 tabulates the fraction of users which mention that they utilize various tools on their job in the three German data sets. Computer usage has increased markedly from 1979 to 1991. Desk or hand calculators (the 1979 data also include cash registers in this category) are used more heavily and their usage has also increased substantially during this period. Telephones are used by about half the work force; with little change during this period. Approximately $60 \%$ of workers use a pen, pencil or other writing material on their job. Furthermore, we use a variable whether employees predominantly work while sitting. The 1985/86 survey had a direct question on how often respondents sit at their job, allowing five possible answers: basically never, rarely, occasionally, often, almost always. We classified those responding "often" or "almost always" as sitting. In 1979 the only similar question asked how often respondents stand, allowing the same five responses. We classified those standing "never" or "rarely" as sitting. There is no such variable in the 1991/92 survey. The fractions sitting differ between the two years; this is likely to be due to the differences in our variable definitions. To compare persons associated with office work or more supervisory roles to blue collar workers, we also consider the usage of manual hand tools, like hammers, screw drivers, paint brushes, hand operated drills, etc. About $30 \%$ of workers use such tools.

Table 4 investigates the wage differentials associated with these various tools. In first panel of the table we report results from regressions similar to those reported in Table 2 except that we separately include each of our tools used on the job. Workers who use a calculator on their job earn 9 to 13 percent more than those who did not. Telephones are associated with a 12 to 14 percent differential, the use of writing materials is associated with an 11 to 13 percent differential, while sitting yields 10 percent higher wages.

While it is plausible that the use of calculators or telephones raises productivity, it is unlikely that the productivity differential of using a computer, a telephone, a pencil or a chair are all basically the same. Instead, what we are obviously capturing is the fact that all these variables are associated with "office" jobs, which are typically higher paying than jobs not involving desk work. Any of these variables, therefore, might indicate that the users of office equipment are more skilled than the non-users, or perform different tasks, or that such workers are more likely to have access to office tools. This interpretation is corroborated by the wage differential observed for using tools associated with relatively unskilled blue collar work: the users of 
simple hand tools earn about 10 percent less than nonusers.

To control for the part of the wage differential attributable simply to occupational wage differentials, the last three columns of table 4 present results from the same regressions but which include a very detailed set of occupation dummies. The wage differential associated with computer use, as well as those for the other tools, drop to about 30 to 50 percent of their original value. Thus, a large fraction of the original differentials are indeed associated with occupations. Nevertheless, differences in wages in the order of 4 to 7 percent remain for the users of the various office tools even within narrowly defined occupations. This again mirrors the within occupation estimates reported by Krueger (1993) for the U.S.

Finally, to control for the possibility that the use of pencils, calculators, etc. might simply be proxying for the use of a computer we include all five office tool dummy variables together and report the results in the bottom panel of Table 4 (the 1991/92 results do not include sitting). While the differential associated with each falls, they all stay individually significant. The computer differential with 7 to 13 percent is among the largest, but the differentials for telephones and jobs which involve sitting also remain in the order of 5 to 7 percent. This result is less surprising if each of these variables proxies for worker ability or a particular type of job; none of the proxies are perfect and some are more important than others. Clearly, however, the use of telephones or pens did not purely proxy for computer use! The results are again qualitatively similar when we include occupations.

In addition, we also reanalyzed the High School and Beyond data for Sophomores and Seniors in 1980 (HSB) used by Krueger (1993). Briefly, HSB is a longitudinal data set that contains inter alia information on computer use, acheivement test scores and school performance for individuals who were sophomores or seniors in 1980. As Kruger notes, information on computer use was collected only in the 1984 wave of the survey and students were only asked whether they had ever used a computer on a job. We follow Krueger and use the information as if it referred to the current job, although this may not be the case for some proportion of the individuals.

In table 5 we exactly replicate the results in Krueger's table VI, columns $(2),(3)$, and $(4)^{3}$. The various regressions include a different set of covariates,

\footnotetext{
${ }^{3}$ We are grateful to Alan Krueger for providing his programs and to Mike Boozer for help above and beyond the call of duty.
} 
however, we only display the coefficient on the computer variable. Krueger's results are shown in the first line. Eliminating missing values on the calculator and VCR variables yields a slightly smaller sample. The coefficients on the computer dummy in this sample are shown in Panel A. The deletions do not make any difference to the estimated coefficients. Panel B shows the returns to using a calculator on the job. The coefficients are positive, marginally significant, but are only one fifth the size of the computer coefficient and only one fourth to one sixth the size of the calculator coefficient for Germany. Part of the differences may reflect real differences between Germany and the U.S. Part of the difference may be the consequence of the fact that our German sample, being representative of the adult population, is much older than the HSB sample which contains only high school graduates two to four years out of school.

Thus, the patterns of returns are somewhat different in the U.S. from our findings for Germany where we found a positive wage differential associated with the calculators on the job.

\section{B Computer Use Versus Computer Knowledge}

What gets rewarded in a competitive labor market are only skills that are scarce. In competitive labor markets, individuals will not be able to capture returns arising from a new technology, say the assembly line, if everybody else can also use the new technology. Private returns only accrue to those workers who possess a skill like the ability to program a computer or work with business software. If these workers are scarce, their wages should be bid up in the market. In addition, the return should accrue to everybody possessing the skill regardless of whether the worker actually uses a computer on the job or not. This effect results from the labor supply side: worker mobility should result in a uniform differential for all workers with computer skills. This suggests that the correct variable to use in these regressions is computer knowledge rather than computer use. In addition, once computer knowledge is controlled for computer use should not matter independently anymore.

The German 1979 survey allows us to further examine this hypothesis. The key feature of the 1979 data that we use is from a series of questions on job skills possessed by respondents. One of the skills inquired about was computer skills. Table 6 presents a cross tabulation of survey responses 
concerning computer skills and computer use. A key fact from this table is that about two thirds of those who possess computer skills do not use a computer on their job. Curiously, a small fraction of workers actually use computers without any qualification.

In the upper panel of Table 7, we include the computer knowledge dummy in a wage regression. Column 1 and column 5 include the measure of computer knowledge in lieu of a measure of computer use. Indeed, it is apparent that the estimated "returns" are similar for either knowledge or use. When we include dummies for both computer knowledge and computer use, we find that most of the wage differential accrues to the knowledge dummy and not to the use variable, just as the compensating differentials argument outlined above suggests.

There is also the labor demand side to be considered, however. It only makes sense to employ a worker with computer knowledge in a non-computer job if this worker is at least as productive in the alternative job. This argument suggests that the wage differential associated with computer knowledge could equally well be a return to some other skill or worker attribute that is often found in the same workers who possess computer skills. Workers who knew how to use computers in the late 1970s, for example, might have been more enterprising during their education to actually acquire this skill. It could be this entrepreneurial talent and motivation that is rewarded. If one wishes to maintain the argument of skill-biased technical change, it is clear however, that some such unobserved talent has to be present among workers with computer knowledge: this is because 9.8 percent of the employed work force earn a 14 percent wage differential without using computers. Thus, even under the skill-biased technological change explanation unobserved heterogeneity is important. Once this is recognized, it is now a small step to conclude that it might be this unobserved talent, for example entrepreneurial motivation, that is also rewarded among computer users.

The pattern of coefficients in Table 7 is again robust to controlling for the same set of occupations as above. When both the computer use and knowledge variables are entered together with occupation controls (column 7), only the computer knowledge variable remains positive while the coefficient on the computer use dummy falls to zero.

More importantly, while computer knowledge rather than computer use seems to explain the wage differential we found for Germany this still does not explain our findings regarding the other tools used on the job. When 
we replace computer use with one of the other tools, such as pens or pencils (lower panel in Table 7), we find positive wage differentials associated with pencils even after controlling for computer knowledge and detailed occupations. It seems to us that these results are equally consistent with an explanation based on differences in pay across workers who have advanced skills and use white collar tools rather than the productivity effects associated with computer knowledge.

The High School and Beyond Survey contains a variety of variables indicating whether the individual has ever used various software packages or has written programs in a computer language. This could have occurred in school or at work. Using these as indicators for computer knowledge, we run similar regressions as in Table 7 with a subset of the Krueger sample from the $\mathrm{HSB}^{4}$ The results are presented in Table 8 . Unlike in the German data we find no evidence that it is computer knowledge rather than computer use which is rewarded in the labor market. However we should stress that the HSB sample is rather peculiar since it only consists of high school graduates two to four year out of school. These workers may not have had time yet to find the kind of jobs that reward their skills most adequately. Hamilton and Yuen (1995) use the same computer knowledge variables from the HSB and find wage differentials in the order of 8 percent using the 1986 rather than the 1984 wage and including respondents who attended college.

\section{Are Other Ability Controls Adequate?}

One way to address the possibility of unobserved heterogeneity in these regressions is to include other controls for ability. Krueger used data from the High School and Beyond Survey which allowed him to include both a computer dummy and controls for parental background, achievement scores, and school grades. We have measures of secondary school grades in math and German in the 1979 survey as well as information on the father's occupation. Table 7 presents results with these additional regressors (columns 4 and 8). Including grades and parental background does little to change the returns to computer knowledge and the use of computers or pencils. This indicates

\footnotetext{
${ }^{4}$ Our sample has only 4,579 observations since we deleted missing values in the variables indicating software or computer language proficiency. This sample differs slightly from the one we use in Table 5.
} 
that ability controls, such as grades, may only be poor proxies for the types of skills that are ultimately relevant in the workplace. Indeed, even a crude variable, such as the use of pens or pencils, is still able to account for some other worker attribute with a quite substantial reward.

Similarly, Krueger finds no change in the computer coefficient controlling for parental background, test scores, and grades in the HSB data. The problem with these results is that the partial correlation of test scores with wages in the Krueger sample is negative and grades are uncorrelated with wages. This may be due to the fact that the sample is selected to exclude individuals who went on to a college education. Furthermore, the workers in the sample are very young, test results may not be revealed to employers and there might have been insufficient time for the labor market to learn about the skills of these workers (see Gibbons and Farber (1994)). Thus, these ability controls in the HSB may not be reliable controls to assess the possibility that unobserved heterogeneity explains the returns to computer use.

\section{Reconsidering the Evidence}

The preceding analysis sheds some doubts on the interpretation that the computer wage differential arises from the possibility that the introduction of computers into the workplace has changed the productivity and wages of workers who use computers. Instead, the wage differential for the use of a variety of tools at work seems to pick up unobserved heterogeneity among workers. Especially during the diffusion of personal computers at the workplace in the 1980 s it is likely that more highly paid workers were the ones who started to use these first on their jobs. In this section we argue that the results in Krueger (1993) as well as the results found in more recent research are also consistent with this interpretation. In particular we re-examine the following evidence:

1. The computer wage differential is three times as high in the nonunion sector than in the union sector.

2. The computer differential has increased over time in the U.S.

3. The pattern of returns to specific computer tasks is consistent with skill-biased technical change. 
4. Computer use at home is not rewarded as highly as computer use at work.

5. Grouped data "fixed effect" models of the returns to computer use find large wage effects of computers.

6. The returns to use of a computer are higher for those with higher levels of schooling.

1. The computer wage differential is three times as high in the nonunion sector than in the union sector.

This is unsurprising since unions are known to compress the wage structure. Thus, all wage differentials tend to be lower within the union sector. Of course, this ought to be true regardless of whether computers truly capture computer skills or are instead simply measuring the impact of any other work related skills and abilities.

2. The computer differential has increased over time in the U.S.

The simplest model for the introduction of computers in the workplace would suggest that the productivity of the marginal computer worker declines as more computers are introduced in the workplace. However, the observed pattern of increasing wage differentials can easily be reconciled with the skill biased technical change story if the quality and therefore the associated productivity effects of computers increased fast enough. There is little doubt that the quality of computers changed tremendously over the 1980s. On the other hand, the observed pattern is also easy to reconcile with a pure heterogeneity explanation. Returns to skill have increased during the 1980s. Thus, if computer use proxies for work related skills, then the return to computer use should increase alongside with other ability related wage differentials such as the return to schooling.

Krueger argues against this view because of the fast expansion of computer use. If computers are used by the most able workers first or the otherwise most highly paid workers first and then slowly spread to less productive, lower wage groups we should see the computer wage differential fall. However, it is unlikely that the proliferation of computers 
followed such a monotonic pattern. Mainframe computers were typically used directly only by a few specialists or staff positions but not by line managers. These positions are on average better paid, therefore we find a significant computer differential already in 1979 . When personal computers became available, computer use became more decentralized. If PCs slowly spread to more highly paid positions, then the computer differential may well have risen during the 1980s. According to Table 1 , computer use in Germany grew much faster among the more highly educated than among the less educated. This may explain a rising computer wage differential in Germany between 1979 and 1991/92 despite the fact that the returns to skill did not change during this period.

3. The pattern of returns to specific computer tasks is consistent with skillbiased technical change.

The results, however, are also easy to reconcile with unobserved heterogeneity. Krueger finds that the highest wages are paid to those using computers for electronic mail, followed by spreadsheets and then programming. Both electronic mail and spreadsheet use seems to indicate that the user probably occupies a managerial position. Other tasks are associated with lower wages, such as inventory control or computer aided design, although these uses are likely to enhance productivity as much as or more than the more highly rewarded tasks.

4. Computer use at home is not rewarded as highly as computer use at work.

To probe the unobserved heterogeneity explanation, Krueger includes a separate dummy variable for computer use at home and an interaction with computer use at work. The wage differential for using computers at home is about one third of the wage effect of using computers at work. This seems to suggest that the computer dummies reflect more than just productivity effects. In fact, unobserved heterogeneity can explain this pattern if computers proxy for ability and using computers at work is a better proxy than using computers at home.

In addition, using a computer at home may simply proxy for higher earnings and therefore the ability to afford a home computer. In order to probe this idea, we ran regressions in the HSB data including a 
variable for the use of a VCR at home and at work. VCRs are much less likely to be a technology that requires major skills and raises productivity substantially. On the other hand, in the mid 1980s VCRs were relatively expensive, so that earnings are likely to be positively correlated with ownership of a VCR.

Panel $\mathrm{C}$ of Table 5 presents our estimates of the returns to using a VCR at home. The wage differential associated with this is 4 percent. Panel D of Table 5 displays results from a regression for both using a VCR at home and using a VCR at work (only few workers use VCRs on their jobs). The returns are very similar but the coefficients on VCRs at work is not very well determined because of the small sample size. The coefficient on an interaction term between VCR use at home and at work was small and insignificantly different from zero and had no effect on these results. We think the results on VCRs are most easily explained by the fact that the income elasticity for VCRs is positive, while ownership of a consumer durable may not be a good control for ability.

5. Grouped data "fixed effect" models of the return to computer use find large wage effects of computers.

In section III C, we noted that computer use or knowledge may be a better proxy for work related skills than grades, test scores, or family background variables. Therefore, we do not view the result that the computer differential remains after controlling for such ability measures as evidence against the unobserved heterogeneity explanation.

An alternative to controlling directly for ability is to difference out the ability component in a panel regression. There are three studies that we are aware of that have attempted to do this. Entorf, Gollac and Kramarz (1995) analyze French panel data and find that workers who start using computers on their jobs do not get wage increases. Bell (1996) uses the British National Child Development Study and finds that the coefficient on computer use remains at about two thirds of the cross sectional level after differencing. Both these studies use micro data on workers.

One weakness of both studies is that that they lack a first period variable on computer use and have to infer this value. Bell, for example, 
assumes that none of the workers in his sample use computers in 1981, the date of his first wave. An additional problem with the Bell study is that all individuals in the sample are born in the same week, so that it is impossible to control for labor market experience. Since more skilled workers tend to have steeper wage profiles, computer usage may simply be picking up the effects of differences in experience profiles so that his first difference results are still consistent with an unobserved heterogeneity explanation for the computer effect.

Entorf et al. (1995) on the other hand, have information on when individuals began using computers. They use this information to construct measures of computer use in earlier years. The cross-sectional results with the French data are roughly consistent with U.S. and German data using similar human capital covariates. Their estimate of the coefficient on computer use is $7 \%$ in the cross-section. On the other hand, when they re-estimate these models with fixed effects they find an estimate of less than one percent. ${ }^{5}$

Another study that presents first differenced results for the effect of advanced technologies on wages is Chennells and Van Reenen (1995). This study also uses U.K. data, but their data are average wages at the firm level. The data come from the Work Place Industrial Relations Survey. They find that the effect of the firm using advanced technologies on the average wages of skilled workers increases from 0.053 in the cross section to 0.135 in first differences. However, it is unclear whether this is compelling evidence either. Investment of firms tends to be correlated with cash flow and profitability (Fazzari, Hubbard and Petersen 1988) and more profitable firms tend to pay higher wages (Blanchflower, Oswald and Sanfey (1992), Estevao and Tevlin (1995)).

Krueger tries to address this issue by running wage regressions using "first-differences" of data grouped by three digit occupations. As long as the composition of occupation groups does not change over time, this procedure effectively eliminates any bias in the estimates due to unobserved heterogeneity. While we agree that it is plausible that the composition of occupations changes rather slowly, interpreting fixed

\footnotetext{
${ }^{5}$ These finding are consistent with results found in Card, Kramarz and Lemieux (1995) for France using cell means for various demographic groups.
} 
effects coefficients for a period when returns are changing is more difficult. We know that wages increased the fastest in more highly skilled occupations during the 1980s. A positive coefficient in the grouped regression is consistent with the unobserved heterogeneity explanation, if these are also the occupations in which computer use grew the most in the 1980s. If this latter explanation is correct, then the effect of the change in computer usage should disappear once we control for a variable which captures the initial skill level in the occupation.

In order to investigate this, we replicated Krueger's occupation level regressions from the CPS. These are displayed in Table 9. Our results differ slightly from those reported in Krueger (1993). ${ }^{6}$ Column (1) displays the results from Krueger's paper and column (2) shows our results when only the change in the fraction of workers using computers is included in the regression. In column (3) we include the level of 1984 wage. Since wage growth was higher for workers earning higher wages initially (Card and Lemieux 1996) this might control better for unobserved heterogeneity than the change in computer use. However, we find that this is not the case; the computer variable actually becomes even more important while the base wage is insignificant. The base wage is problematic because temporary components in the wage and sampling error will lead to a spurious negative correlation between the change and the lagged level of the variable. Autor, Katz and Krueger (1995), who are exploring these issues concurrently with our paper, suggest using the average education level in the occupation in the base period. This is a powerful predictor of wage growth in the occupation (note well the increase in the $\mathrm{R}^{2}$ ). Computer use becomes negative and insignificant once schooling is controlled for. This indicates that these regressions are not very robust to changes in specification. Wage growth in an occupation in the 1980s seems more closely related to the skill level in the occupation than to the growth in computer utilization.

6. The returns to use of a computer are higher for those with higher levels of schooling

\footnotetext{
${ }^{6}$ See Appendix for details on our sample. We are grateful to David Autor, who has also attempted to replicate Krueger's results, for many useful discussions.
} 
The interaction between computer use and education in the U.S. is positive, significant, and increasing over time. This is consistent with the skill-biased technical change explanation. Computers make workers more productive. The productivity effect is larger for more skilled workers, for example for those with higher education. Since the more educated workers are the ones using more computers in the 1980s, part of the returns to computer use are being captured by education if computer use is not controlled for. Krueger calculates that 40 percent of the increase in returns to education between 1984 and 1989 can be explained by computer use.

The observed pattern for the U.S. is also consistent with unobserved heterogeneity. According to this explanation, computer use proxies for productivity which is rewarded in the labor market. Since the distribution of $\log$ wages is skewed to the right, the returns to unobserved skills might easily be higher for more highly educated workers. ${ }^{7}$ Alternatively, computer use may proxy for more valuable skills among the more highly educated. Furthermore, the spreading of the wage distribution in the 1980s will exacerbate this effect. Therefore, the interaction term between computer use and education might increase over time.

Autor (1994) finds that the interaction between computer use and schooling is not very robust. The returns to school tend to be slightly lower at very low education levels. Workers who haven't completed elementary school very rarely use computers and it may be this nonlinearity that the computer/schooling interaction picks up.

When we interact computer use and education in our German data sets we find the opposite results from those found for the U.S. These results are reported in Table 10. The interaction terms are negative and significant. We find the divergence in results hard to reconcile with a skill biased technical change explanation. Both skills taught in school and technology are not fundamentally different in the U.S. and in Germany. Thus, if computers raised the productivity of the more highly educated to a greater extent than other workers we should see similar interaction terms in both countries. One potential explanation could be that returns for Germany do not reflect marginal products

\footnotetext{
${ }^{7}$ Indeed, this is exactly the argument made in Juhn, Murphy and Pierce (1993).
} 
very well because the German wage structure is too highly regulated. However, if this is the case then we should also find a much lower effect for computer use in Germany but that is not the case. Overall, the empirical evidence for a complementary between computer use and schooling, which is at the core of the skill-biased technological change story, seems rather weak to us.

\section{Conclusion}

Suppose a researcher sets out on a research project to determine the wage differential associated with the use of computers on-the-job. Unfortunately, his research assistant mistakenly pulled a variable "using pen or pencil" instead of the desired variable on computer use. Could the analyst have told the difference merely from the results of wage regressions? ${ }^{8}$ According to our results in this paper we believe that this is unlikely since the wage differentials associated with the use of writing materials and computers look extremely similar. In addition, the wage differentials of tools like pencils remain significant even after controlling for grades, parental background, and a detailed set of occupations. We are reasonably convinced that the use of pens or pencils on the job most likely reflects unobserved heterogeneity among workers and jobs not captured by these alternative controls. This argument is not evidence that the wage differential associated with computer use may not represents returns for some workers generated by the computer revolution. However, there are good reasons to be skeptical about this explanation and instead to entertain the possibility that this coefficient mostly reflects unobserved heterogeneity.

While a number of studies have appeared that have tried to address the unobserved heterogeneity explanation by including fixed effects in panel regressions, these results so far show little regularity. Also, panel data often lack sufficient detail on the introduction of computers at the workplace to make these studies fully convincing. Chennells and Van Reenen (1995) present instrumental variables results using $R \& D$ expenditures and patents at the firm level as an instrument for advanced technologies. While these

\footnotetext{
${ }^{8}$ Obviously, the raw fraction of pencil users is higher than the fraction of computer users, which would have indicated the mistake.
} 
results show little role for a causality running from technology to wages we do not find the exclusion restrictions in these regressions very compelling either.

Our skepticism about the effects of computers on wages is mirrored by the recent literature that has tried to assess the effects of increased computer use on productivity. If the returns to computer use reflect entirely productivity effects, then the estimates in Krueger (1993) suggest that output in the U.S. should have risen by 0.38 percent each year in the mid-1980s according to Sichel and Oliner (1994). They find that computers only raised growth by about 0.16 percentage points using standard growth accounting techniques.

Brynjolfsson and Hitt (1993), on the other hand, find much higher implied productivity effects based on production function estimates using firm level data. According to their estimates, output due to computers should have risen by about 1 additional percentage point per year. As they acknowledge themselves, their estimates are subject to the same problem as Krueger's: firms with computers may be more productive but this may simply be a reflection of unobserved heterogeneity among firms. In addition, their estimates are for the late 1980s and early 1990s. The productivity effects, in particular of PCs, may well have been much larger during this period than during the earlier years when the new technology was first introduced. The introduction of $\mathrm{PCs}$ was probably associated with a substantial period of learning about its most productive uses.

If it is true that it took until the late 1980s for large productivity effects of computers to emerge, labor economists are again in a dilemma. In this case computers are unlikely to be the technology which led to skill-biased technological change. The returns to higher skill have changed relatively rapidly in the earlier part of the 1980s but the spreading of the wage distribution has slowed somewhat since the late 1980s (Bound and Johnson 1995). Thus, the timing of the productivity effects of the personal computer revolution would be entirely wrong to explain the empirical findings about wages. 


\section{Appendix: Construction of the CPS Sample}

The sample we use for for the regressions reported in Table 9 differs slightly from the one used by Krueger (1993); to maintain comparability with his results, however, we followed his procedures rather closely. The computer variable is from all rotation groups of the 1984 and 1989 October CPS supplements. The sample includes all observations with employment status recode 1 or 2, ages 18-64 (this is the age range we believe Krueger (1993) uses although his paper states that the range is $15-65$ ), for which the answer to the computer question is not missing.

The wage and education variables are from the outgoing rotation groups for all twleve months of 1984 and 1989. The samples include individuals with employment status recode 1 or 2 , ages 18-64. The wage variable is constructed as edited or computed earnings per week (the variable earnwke on the National Bureau of Economic Research (NBER) Annual Earnings Files $(\mathrm{AEF})$ ) divided by edited usual hours per week (uhourse in the NBER AEF). For hourly workers this corresponds to their answer to the CPS question 25c. For salaried workers this corresponds to usual earnings per week (item 25d) divided by usual hours. 1989 wages are deflated to 1984 values by the GDP deflator for consumer expenditures. Observations with hourly wages below $\$ 1.50$ or above $\$ 250$ are deleted. The log wage for observations which are topcoded in 1984 (earnwke equal to 999) is set to 3.1 (the mean log wage for all observations with earnwke $\geq 999$ in 1989; this value differs slightly from Krueger's).

Education is years of schooling completed. Observations with missing values for wages or education were deleted before forming cell means by occupation. There are 480 occupations with at least one observation from the wage and the computer sample. The square root of the number of observations in the 1989 wage sample for each occupation is used as weight in the regressions. 


\section{References}

Autor, David H., "Charting the Impact of the Computer Revolution: New Evidence from the Current Population Survey," Mimeo, Harvard University 1995 .

, Lawrence F. Katz, and Alan Krueger, "How Compuers are Changing the Labor Market," Mimeo, Harvard University 1995.

Bell, Brian D., "Skill-Biased Technical Change and Wages: Evidence from a Longitudinal Data Set," Mimeo, Nuffield College, Oxford March 1996.

Blanchflower, D., A. Oswald, and P. Sanfey, "Wages, Profit, and Rent Sharing," Mimeo, Dartmouth College 1992.

Bound, John and George Johnson, "Changes in the Structure of Wages in the 1980s: An Evaluation of Alternative Explanations," American Economic Review, June 1992, 82, 371-392.

__ and _ , "What are the Causes of Rising Inequality in the United States?," Economic Policy Review, January 1995, 1, 9-17.

Brynjolfsson, Erik and Lorin Hitt, "New on the Returns to Information Technologies," Technical Report, Center for Coordination Science,Sloan School of Management, Massachusetts Institute of Technology 1993.

Card, David and Thomas Lemieux, "Wage Dispersion, Returns to Skill, and Black-White Differentials," Journal of Econometrics 1996, forthcoming.

_ , Francis Kramarz, and Thomas Lemieux, "Changes in the Relative Structure of Wages and Employment: A Comparison of the United States, Canada, and France," Industrial Relations Section Working Paper 355, Princeton University December 1995.

Chennells, Lucy and John Van Reenen, "Wages and technology in British plants: do workers get a fair share of the plunder?," Mimeo, Institute for Fiscal Studies April 1995.

Entorf, Horst, Michel Gollac, and Francis Kramarz, "New Technologies, Wages, and Worker Selection," INSEE Working Paper 1995. 
Estevao, Marcello and Stacey Tevlin, "The Role of Profits in Wage Determination: Evidence from U.S. Manufacturing," Mimeo, MIT 1995.

Fazzari, Steven, R. Glen Hubbard, and Bruce Petersen, "Financing Constraints on Corporate Investment," Brooking Papers on Economic Activity, 1988, 1, 141-195.

Gibbons, Robert and Henry Farber, "Learning and Wage Determination," Industrial Relations Section Working Paper 328, Princeton University 1994.

Hamilton, Barton and Raymond Yuen, "Self-Selection and the Returns to Computer Skills Among Young Workers," Mimeo, McGill University May 1995.

Juhn, Chinhui, Kevin M. Murphy, and Brooks Pierce, "Wage Inequality and the Rise in the Returns to Skill," Journal of Political Economy, June 1993, 101 (3), 410-442.

Krueger, Alan, "How Computers Have Changed the Wage Structure: Evidence from Microdata, 1984-1989," Quarterly Journal of Economics, February 1993, 108, 33-60.

and Jörn-Steffen Pischke, "A Comparative Analysis of East and West German Labor Markets: Before and After Unification," in Richard Freeman and Larry Katz, eds., Differences and Changes in Wage Structures, Chicago: University of Chicago Press and NBER, 1995.

Krugman, Paul, "Past and Prospective Causes of High Unemployment," in "Reducing Unemployment: Current Issues and Options," Vol. 1, Federal Reserve Bank of Kansas City, 1994.

Schlesinger, Tom, Our Own Worst Enemey, Tennessee: Highlander Center: New Market, 1983.

Sichel, Daniel E. and Stephen D. Oliner, "Computers and Output Growth Revisited: How Big is the Puzzle," Brookings Papers on Economic Activity, 1994, 2, 273-333. 
Table 1:

Percent of Workers in Various Categories Who Use Computers at Work

\begin{tabular}{lccccc}
\hline Group & US & US & Germany & Germany & Germany \\
& 1984 & 1989 & 1979 & $1985 / 86$ & $1991 / 92$ \\
\hline All workers & 24.6 & 37.4 & 8.5 & 18.5 & 35.3 \\
Men & 21.2 & 32.3 & 7.9 & 18.5 & 36.4 \\
Women & 29.0 & 43.4 & 9.7 & 18.5 & 33.5 \\
Less than high school & 5.0 & 7.8 & 3.2 & 4.3 & 9.9 \\
High school & 19.3 & 29.3 & 8.5 & 18.3 & 32.7 \\
Some college & 30.6 & 45.3 & 8.5 & 24.8 & 48.4 \\
College & 41.6 & 58.2 & 17.1 & 40.3 & 67.8 \\
Postcollege & 42.8 & 59.7 & 11.6 & 26.5 & 58.5 \\
Age 18-24 & 19.7 & 29.4 & 10.1 & 13.8 & 27.8 \\
Age 25-39 & 29.2 & 41.5 & 9.6 & 21.6 & 39.9 \\
Age 40-54 & 23.6 & 39.1 & 6.6 & 17.2 & 35.9 \\
Age 55-65 & 16.9 & 26.3 & 5.8 & 13.5 & 23.6 \\
Blue collar & 7.1 & 11.6 & 1.2 & 3.5 & 10.6 \\
White Collar & 33.0 & 48.4 & 12.8 & 28.8 & 50.1 \\
Part time & 23.7 & 36.3 & 6.4 & 14.7 & 26.5 \\
Full time & 28.9 & 41.1 & 8.7 & 19.0 & 37.0 \\
Number of Obs. & 13335 & 13379 & 19482 & 22414 & 20090 \\
\hline
\end{tabular}

Columns 1 and 2 are from Krueger (1993) and come from the October Current Population Survey. German data are from the Qualification and Career Survey. 
Table 2:

OLS Regressions for the Effect of Computer Use on Pay Dependent Variable: Log Hourly Wage (Standard Errors in Parentheses)

\begin{tabular}{lccccc}
\hline Independent & US & US & Germany & Germany & Germany \\
variable & 1984 & 1989 & 1979 & $1985 / 86$ & $1991 / 92$ \\
\hline Computer & 0.170 & 0.188 & 0.112 & 0.157 & 0.171 \\
& $(0.008)$ & $(0.008)$ & $(0.010)$ & $(0.007)$ & $(0.006)$ \\
Years of schooling & 0.069 & 0.075 & 0.073 & 0.064 & 0.072 \\
& $(0.001)$ & $(0.002)$ & $(0.001)$ & $(0.001)$ & $(0.001)$ \\
Experience & 0.027 & 0.027 & 0.030 & 0.035 & 0.030 \\
& $(0.001)$ & $(0.001)$ & $(0.001)$ & $(0.001)$ & $(0.001)$ \\
Experience2/100 & -0.041 & -0.041 & -0.052 & -0.057 & -0.046 \\
& $(0.002)$ & $(0.002)$ & $(0.002)$ & $(0.002)$ & $(0.002)$ \\
Part time & -0.256 & -0.221 & -0.122 & -0.034 & 0.015 \\
& $(0.010)$ & $(0.010)$ & $(0.012)$ & $(0.009)$ & $(0.009)$ \\
In SMSA/City & 0.111 & 0.138 & 0.051 & 0.059 & -0.007 \\
& $(0.007)$ & $(0.007)$ & $(0.006)$ & $(0.006)$ & $(0.006)$ \\
Female & -0.162 & -0.172 & -0.099 & -0.114 & -0.150 \\
& $(0.012)$ & $(0.012)$ & $(0.010)$ & $(0.010)$ & $(0.010)$ \\
Married & 0.156 & 0.159 & 0.119 & 0.117 & 0.083 \\
& $(0.011)$ & $(0.011)$ & $(0.009)$ & $(0.008)$ & $(0.009)$ \\
Female*Married & -0.168 & 0.182 & -0.169 & -0.152 & -0.104 \\
& $(0.015)$ & $(0.010)$ & $(0.013)$ & $(0.013)$ & $(0.012)$ \\
$R^{2}$ & 0.446 & 0.451 & 0.266 & 0.280 & 0.335 \\
Number of Obs. & 13335 & 13379 & 19482 & 22414 & 20090 \\
\hline
\end{tabular}

Columns 1 and 2 are from table II in Krueger (1993). Columns 3-5 also include a dummy variable for civil servant (Beamter.) All models also include an intercept. Data the same as in Table 1. 
Table 3:

Fraction of Workers Using Different Tools on Their Job

\begin{tabular}{lccc}
\hline & $\begin{array}{c}\text { Germany } \\
1979\end{array}$ & $\begin{array}{c}\text { Germany } \\
1985 / 86\end{array}$ & $\begin{array}{c}\text { Germany } \\
1991 / 92\end{array}$ \\
& & & \\
\hline Computer & 0.085 & 0.185 & 0.353 \\
Calculator & 0.195 & 0.357 & 0.441 \\
Telephone & 0.418 & 0.438 & 0.584 \\
Pen/Pencil & 0.549 & 0.534 & 0.656 \\
Work while sitting $^{a}$ & 0.308 & 0.194 & - \\
Hand tool (e.g. hammer) & 0.294 & 0.329 & 0.306 \\
\hline
\end{tabular}

a Variable definition differs in 1979 and 1985/86. In 1979 it refers to "Never or rarely standing," and in 1986/6 it refers to "Often or almost always sitting."

Data is the same as in Table 1. 
Table 4:

OLS Regressions for the Effect of Different Tools on Pay

Dependent Variable: Log Hourly Wage

(Standard Errors in Parentheses)

\begin{tabular}{|c|c|c|c|c|c|c|}
\hline $\begin{array}{l}\text { Independent } \\
\text { variable }\end{array}$ & $\begin{array}{c}\text { Germany } \\
1979\end{array}$ & $\begin{array}{c}\text { Germany } \\
1985 / 86\end{array}$ & $\begin{array}{c}\text { Germany } \\
1991 / 92\end{array}$ & $\begin{array}{c}\text { Germany } \\
1979\end{array}$ & $\begin{array}{c}\text { Germany } \\
1985 / 86\end{array}$ & $\begin{array}{c}\text { Germany } \\
1991 / 92\end{array}$ \\
\hline \multicolumn{7}{|c|}{ Occupation Indicators } \\
\hline & No & No & No & 501 & 745 & 1073 \\
\hline & \multicolumn{6}{|c|}{ Tools entered separately } \\
\hline Computer & $\begin{array}{c}0.112 \\
(0.010)\end{array}$ & $\begin{array}{c}0.157 \\
(0.007)\end{array}$ & $\begin{array}{c}0.171 \\
(0.006)\end{array}$ & $\begin{array}{c}0.025 \\
(0.011)\end{array}$ & $\begin{array}{c}0.076 \\
(0.008)\end{array}$ & $\begin{array}{c}0.083 \\
(0.007)\end{array}$ \\
\hline Calculator & $\begin{array}{c}0.088 \\
(0.007)\end{array}$ & $\begin{array}{c}0.128 \\
(0.006)\end{array}$ & $\begin{array}{c}0.129 \\
(0.006)\end{array}$ & $\begin{array}{c}0.027 \\
(0.008)\end{array}$ & $\begin{array}{c}0.062 \\
(0.007)\end{array}$ & $\begin{array}{c}0.054 \\
(0.006)\end{array}$ \\
\hline Telephone & $\begin{array}{c}0.131 \\
(0.006)\end{array}$ & $\begin{array}{l}0.115 \\
(0.006)\end{array}$ & $\begin{array}{c}0.136 \\
(0.006)\end{array}$ & $\begin{array}{c}0.060 \\
(0.007)\end{array}$ & $\begin{array}{c}0.059 \\
(0.007)\end{array}$ & $\begin{array}{c}0.072 \\
(0.007)\end{array}$ \\
\hline Pen/Pencil & $\begin{array}{c}0.122 \\
(0.006)\end{array}$ & $\begin{array}{c}0.112 \\
(0.006)\end{array}$ & $\begin{array}{c}0.127 \\
(0.006)\end{array}$ & $\begin{array}{c}0.054 \\
(0.007)\end{array}$ & $\begin{array}{c}0.055 \\
(0.007)\end{array}$ & $\begin{array}{c}0.050 \\
(0.007)\end{array}$ \\
\hline Work while sitting & $\begin{array}{c}0.105 \\
(0.006)\end{array}$ & $\begin{array}{c}0.102 \\
(0.007)\end{array}$ & - & $\begin{array}{c}0.042 \\
(0.008)\end{array}$ & $\begin{array}{c}0.036 \\
(0.008)\end{array}$ & - \\
\hline $\begin{array}{l}\text { Hand tool } \\
\text { (e.g. hammer) }\end{array}$ & $\begin{array}{c}-0.117 \\
(0.006)\end{array}$ & $\begin{array}{c}-0.087 \\
(0.006)\end{array}$ & $\begin{array}{c}-0.092 \\
(0.006) \\
\end{array}$ & - & - & - \\
\hline & \multicolumn{6}{|c|}{ Tools entered together } \\
\hline Computer & $\begin{array}{c}0.067 \\
(0.010)\end{array}$ & $\begin{array}{c}0.105 \\
(0.008)\end{array}$ & $\begin{array}{c}0.126 \\
(0.007)\end{array}$ & $\begin{array}{c}0.027 \\
(0.011)\end{array}$ & $\begin{array}{c}0.067 \\
(0.008)\end{array}$ & $\begin{array}{c}0.069 \\
(0.007)\end{array}$ \\
\hline Calculator & $\begin{array}{c}0.017 \\
(0.008)\end{array}$ & $\begin{array}{c}0.054 \\
(0.007)\end{array}$ & $\begin{array}{c}0.044 \\
(0.007)\end{array}$ & $\begin{array}{c}0.016 \\
(0.008)\end{array}$ & $\begin{array}{c}0.033 \\
(0.007)\end{array}$ & $\begin{array}{c}0.022 \\
(0.007)\end{array}$ \\
\hline Telephone & $\begin{array}{c}0.072 \\
(0.007)\end{array}$ & $\begin{array}{c}0.044 \\
(0.008)\end{array}$ & $\begin{array}{c}0.045 \\
(0.008)\end{array}$ & $\begin{array}{c}0.044 \\
(0.008)\end{array}$ & $\begin{array}{c}0.035 \\
(0.008)\end{array}$ & $\begin{array}{c}0.048 \\
(0.008)\end{array}$ \\
\hline Pen/Pencil & $\begin{array}{c}0.061 \\
(0.007)\end{array}$ & $\begin{array}{c}0.030 \\
(0.008)\end{array}$ & $\begin{array}{c}0.036 \\
(0.008)\end{array}$ & $\begin{array}{c}0.039 \\
(0.008)\end{array}$ & $\begin{array}{c}0.024 \\
(0.008)\end{array}$ & $\begin{array}{c}0.007 \\
(0.008)\end{array}$ \\
\hline Work while sitting & $\begin{array}{c}0.058 \\
(0.007)\end{array}$ & $\begin{array}{c}0.051 \\
(0.007)\end{array}$ & - & $\begin{array}{c}0.036 \\
(0.008)\end{array}$ & $\begin{array}{c}0.033 \\
(0.008)\end{array}$ & - \\
\hline
\end{tabular}

Data is same as in Table 1. All regressions also include an intercept, years of schooling, experience and experience squared, dummies for part-time, city, female, married, married*female, and for civil servants. 
Table 5:

OLS Wage Regressions with High School and Beyond Data (US)

Dependent Variable Log Hourly Wages

(Standard Errors in Parentheses)

\begin{tabular}{|c|c|c|c|}
\hline Specification & $\begin{array}{c}\text { As Krueger } \\
\text { Col. } 2\end{array}$ & $\begin{array}{l}\text { As Krueger } \\
\text { Col. 3 }\end{array}$ & $\begin{array}{c}\text { As Krueger } \\
\text { Col. } 4\end{array}$ \\
\hline \multirow[b]{2}{*}{ Computer } & \multicolumn{3}{|c|}{ Krueger Sample } \\
\hline & $\begin{array}{c}0.114 \\
(0.015) \\
\end{array}$ & $\begin{array}{c}0.110 \\
(0.015) \\
\end{array}$ & $\begin{array}{c}0.111 \\
(0.015)\end{array}$ \\
\hline \multirow[b]{2}{*}{ Computer } & \multicolumn{3}{|c|}{ Our Sample } \\
\hline & $\begin{array}{c}0.115 \\
(0.015)\end{array}$ & $\begin{array}{c}0.111 \\
(0.015)\end{array}$ & $\begin{array}{c}0.111 \\
(0.015)\end{array}$ \\
\hline Calculator & $\begin{array}{c}0.021 \\
(0.012) \\
\end{array}$ & $\begin{array}{c}\mathrm{B} \\
0.023 \\
(0.012)\end{array}$ & $\begin{array}{c}0.024 \\
(0.012) \\
\end{array}$ \\
\hline \multirow[t]{2}{*}{$\begin{array}{l}\text { VCR } \\
\text { At home }\end{array}$} & $\begin{array}{c}0.048 \\
(0.012)\end{array}$ & $\begin{array}{c}\mathrm{C} \\
0.041 \\
(0.012)\end{array}$ & $\begin{array}{c}0.042 \\
(0.012)\end{array}$ \\
\hline & \multicolumn{3}{|c|}{$\mathrm{D}$} \\
\hline VCR & 0.048 & 0.041 & 0.042 \\
\hline At home & $(0.012)$ & $(0.012)$ & $(0.012)$ \\
\hline VCR & 0.042 & 0.040 & 0.041 \\
\hline At work & $(0.023)$ & $(0.023)$ & $(0.023)$ \\
\hline
\end{tabular}

Our sample refers to the subset of Krueger's sample that deletes observations with missing values for VCR and calculator use. For details on Krueger's sample see Krueger (1993). Krueger col. 2 also includes an intercept, dummies for female, black, other race, married, married $^{*}$ fernale, union member, senior in 1980, and native born. Krueger col. 3 includes in addition two dummies for high school type, a dummy for urban high school, and 9 region dummies. Krueger col. 4 includes in addition 10 dummies for parents' education, 1980 test scores, GPA, and dummies for disciplinary problems and disabilities. 
Table 6:

Cross Tabulation of Computer Use and Computer Knowledge

1979 German Data

Percent of Total Sample

\begin{tabular}{lccc}
\hline & No Computer & Computer & Marginal \\
& Knowlege & Knowledge & \\
Don't use computer & 81.7 & 9.8 & 91.5 \\
Use computer & 2.6 & 5.9 & 8.5 \\
Marginal & 84.3 & 15.8 & 100.0 \\
\hline
\end{tabular}

Data are the same as in table 1. 
Table 7:

OLS Regressions for the Effect of Computers Use and Knowledge on Pay 1979 German Data

Dependent Variable: Log Hourly Wage

(Standard Errors in Parentheses)

\begin{tabular}{|c|c|c|c|c|c|c|c|c|}
\hline \multicolumn{9}{|c|}{ Computer Use } \\
\hline Independent variable & (1) & $(2)$ & $(3)$ & (4) & (5) & (6) & $(7)$ & (8) \\
\hline Computer use & $\begin{array}{c}0.112 \\
(0.010)\end{array}$ & - & $\begin{array}{c}0.041 \\
(0.011)\end{array}$ & $\begin{array}{c}0.034 \\
(0.011)\end{array}$ & $\begin{array}{c}.025 \\
(0.011)\end{array}$ & - & $\begin{array}{c}0.002 \\
(0.011)\end{array}$ & $\begin{array}{l}-0.000 \\
(0.011)\end{array}$ \\
\hline $\begin{array}{l}\text { Computer } \\
\text { Knowledge }\end{array}$ & - & $\begin{array}{c}0.138 \\
(0.009)\end{array}$ & $\begin{array}{c}0.124 \\
(0.008)\end{array}$ & $\begin{array}{l}0.0109 \\
(0.009)\end{array}$ & - & $\begin{array}{c}0.057 \\
(0.008)\end{array}$ & $\begin{array}{c}0.056 \\
(0.009)\end{array}$ & $\begin{array}{c}0.053 \\
(0.009)\end{array}$ \\
\hline $\begin{array}{l}\text { Grades and } \\
\text { Father's occupation }\end{array}$ & no & no & no & yes & no & no & no & yes \\
\hline Occupation Dummies & no & no & no & no & yes & yes & yes & yes \\
\hline \multicolumn{9}{|c|}{ Pencil Use } \\
\hline Pencil use & $\begin{array}{c}0.122 \\
(0.006)\end{array}$ & - & $\begin{array}{c}0.106 \\
(0.006)\end{array}$ & $\begin{array}{c}0.096 \\
(0.006)\end{array}$ & $\begin{array}{c}0.054 \\
(0.007)\end{array}$ & - & $\begin{array}{c}0.053 \\
(0.007)\end{array}$ & $\begin{array}{c}0.051 \\
(0.007)\end{array}$ \\
\hline $\begin{array}{l}\text { Computer } \\
\text { Knowledge }\end{array}$ & - & $\begin{array}{c}0.138 \\
(0.009)\end{array}$ & $\begin{array}{c}0.056 \\
(0.008)\end{array}$ & $\begin{array}{c}0.052 \\
(0.008)\end{array}$ & - & $\begin{array}{c}0.057 \\
(0.008)\end{array}$ & $\begin{array}{c}0.056 \\
(0.008)\end{array}$ & $\begin{array}{c}0.052 \\
(0.008)\end{array}$ \\
\hline $\begin{array}{l}\text { Grades and } \\
\text { Father's occupation }\end{array}$ & no & no & no & yes & no & no & no & yes \\
\hline Occupation Dummies & no & no & no & no & yes & yes & yes & yes \\
\hline
\end{tabular}

Data are the same as in table 1. Regressions also include an intercept, years of schooling, experience and experience squared, dummies for part-time, city, female, married, married*female, and for civil servants. Grades are self-reported grades in math and German. 10 dummies for fathers' occupation are included where indicated. 
Table 8:

OLS Regressions for the Effect of Computers Use and Knowledge on Pay

High School and Beyond Data (US)

Dependent Variable: Log Hourly Wage

(Standard Errors in Parentheses)

\begin{tabular}{lcccccc}
\hline Independent variable & $(1)$ & $(2)$ & $(3)$ & $(4)$ & $(5)$ & $(6)$ \\
Computer use & 0.115 & - & 0.128 & 0.111 & - & 0.121 \\
& $(0.015)$ & & $(0.016)$ & $(0.015)$ & & $(0.016)$ \\
Computer & - & -0.006 & -0.036 & - & -0.002 & -0.030 \\
Knowledge & & $(0.012)$ & $(0.013)$ & & $(0.013)$ & $(0.013)$ \\
$\begin{array}{l}\text { Grades, } \\
\begin{array}{l}\text { Parents' education } \\
\text { and other controls }\end{array}\end{array}$ & no & no & no & yes & yes & yes \\
\hline
\end{tabular}

All specifications include an intercept, dummies for female, black, other race, married, union member, senior in 1980, age and age squared, and native born. Columns 4-6 also include two dummies for high school type, a dummy for urban high school, and 9 region dummies, 10 dummies for parents' education, 1980 test scores, GPA, and dummies for disciplinary problems and disabilities.

Table 9:

Weighted Least Squares Regressions with Current Population Survey(US) Dependent Variable: Change in Mean Log Hourly Wages

(Standard Errors in Parentheses)

\begin{tabular}{lcccc}
\hline Specification & As Krueger & Our Sample & Our Sample & Our Sample \\
\hline$\Delta$ Computer & 0.105 & 0.095 & 0.113 & -0.048 \\
& $(0.029)$ & $(0.035)$ & $(0.034)$ & $(0.038)$ \\
1984 Log Wage & - & - & -0.016 & - \\
& & - & $(0.011)$ & \\
1984 Eduation & - & - & - & 0.016 \\
$\mathrm{R}^{2}$ & 0.03 & 0.02 & 0.02 & $0.002)$ \\
\hline
\end{tabular}

Sample consists of means for 485 occupations (Krueger) and 480 occupations (our sample). Computer use is calculated from the Octorber CPS while wages and education are calculated from the outgoing rotation group files for the entire year. 1989 cell sizes are used as weights. See the Appendix for details. 
Table 10:

OLS Regressions: Computer Use Interacted With Years of Schooling Dependent Variable: Log Hourly Wages

(Standard Errors in Parentheses)

\begin{tabular}{lccccc}
\hline Independent & U.S. & U.S. & Germany & Germany & Germany \\
variable & 1984 & 1989 & 1979 & $1985 / 86$ & $1991 / 92$ \\
\hline Use Computer & 0.073 & 0.005 & 0.403 & 0.446 & 0.514 \\
& $(0.048)$ & $(0.043)$ & $(0.056)$ & $(0.036)$ & $(0.029)$ \\
Use Computer $\times$ Yrs. School & 0.007 & 0.013 & -0.023 & -0.022 & -0.027 \\
& $(0.003)$ & $(0.003)$ & $(0.004)$ & $(0.003)$ & $(0.002)$ \\
Yrs. School & 0.067 & 0.071 & 0.076 & 0.068 & 0.084 \\
& $(0.002)$ & $(0.002)$ & $(0.002)$ & $(0.001)$ & $(0.002)$ \\
\hline
\end{tabular}

Data is the same as in Table 1. Regressions also include an intercept, experience, experience squared, dummies for part-time, city, female, married, and married*female. Models for Germany also include a dummy for civil servants. 